\title{
ANALISIS IMPLEMENTASI PRO-POOR BUDGETING PEMERINTAH KOTA SALATIGA DI MASA PENDEMI COVID-19 TAHUN 2020
}

\author{
Suryo Sakti Hadiwijoyo ${ }^{1)}$ \\ Putri Hergianasari ${ }^{2}$
}

\author{
Fakultas Ilmu Sosial dan Ilmu Komunikasi, Universitas Kristen Satya Wacana ${ }^{1,2}$ \\ suryo.hadiwijoyo@uksw.edu ${ }^{1}$,putri.hergianasari@uksw.edu ${ }^{2}$
}

\begin{abstract}
ABSTRAK
Pandemi Covid-19 berimplikasi pada tingkat kesejahteraan masyarakat Kota Salatiga. Penelitian bertujuan menganalisis penerapan Pro-Poor Budgeting di Pemerintah Kota Salatiga saat Pandemi Covid-19. Penelitian dibatasi pada penerapan Pro-Poor Budgeting Kota Salatiga tahun 2020. Metode yang digunakan yaitu deskriptif kualitatif dengan wawancara dan studi lapangan ke Bappeda Kota Salatiga. Hasil penelitian implementasi penganggaran bagi program penanggulangan kemiskinan sudah memperhatikan prinsip-prinsip dalam Pro Poor Budgeting yaitu sasaran adalah warga miskin, fokus pada akar masalah kemiskinan, memaksimal manfaat bagi orang miskin dan melibatkan partisipasi warga miskin. Kesimpulan, dalam implementasi Pro Poor Budgeting, terdapat tiga isu strategis yang menjadi fokus perhatian yaitu sinkronisasi data keluarga miskin dengan data dari masyarakat terdampak Covid-19 dari mitra binaan yang dimiliki oleh Perangkat Daerah, Standart Operasional Prosedur (SOP) pelaksanaan program terutama yang berkaitan dengan masyarakat terdampak Covid-19 dan inovasi program kegiatan yang mempunyai daya ungkit bagi peningkatan ekonomi masyarakat. Selain itu keberhasilan implementasi Pro Poor Budgeting maupun penanganan isu straegis tersebut dipengaruhi empat aspek yaitu struktur birokrasi, sumberdaya, disposisi, dan komunikasi.
\end{abstract}

Kata kunci: Implementasi Kebijakan, Pandemi Covid-19, Pemerintah Kota Salatiga, Pro Poor Budgeting

\begin{abstract}
The Covid-19 pandemic has implications for the welfare level of the people of Salatiga City. This study aims to analyze the implementation of Pro-Poor Budgeting in the Salatiga City Government during the Covid-19 Pandemic. The research is limited to the application of Pro-Poor Budgeting for the City of Salatiga in 2020. The method used is descriptive qualitative with interviews and field studies to the Bappeda of Salatiga City. The results of the research on the implementation of budgeting for poverty reduction programs have taken into account the principles in Pro Poor Budgeting, namely the target is the poor, focuses on the root causes of poverty, maximizes benefits for the poor and involves the participation of the poor. In conclusion, in the implementation of Pro Poor Budgeting, there are three strategic issues that are the focus of attention, namely synchronization of data on poor families with data from communities affected by Covid-19 from fostered partners owned by Regional Apparatuses, Standard Operating Procedures (SOP) for program implementation, especially those related to communities affected by Covid-19 and innovative activity programs that have the power to improve the community's economy. In addition, the success of the implementation of Pro Poor Budgeting and the handling of strategic issues is influenced by four aspects, namely bureaucratic structure, resources, disposition, and communication.
\end{abstract}

Keywords: Policy Implementaion, Covid-19 Pandemic, Salatiga City Government, Pro Poor Budgeting,

\section{PENDAHULUAN}

Kemiskinan merupakan masalah yang bersifat multidimensi dan lintas negara, bahkan kemiskinan juga menjadi isu global yang harus ditangani oleh semua negara dan semua aktor non negara. Kemiskinan selalu menjadi isu prioritas dalam pembangunan global. (Wahyuningsih, 
2018) Strategisnya isu kemiskinan dalam agenda pembangunan global, ditunjukkan dengan ditempatkannya isu kemiskinan sebagai tujuan pertama (Goal-1), baik dalam MDGs ataupun SDGs.(Vernon, 2015) WHO pada Bulan Maret 2020 menyatakan bahwa Covid-19 merupakan pandemik global membawa implikasi yang luar biasa dalam berbagai aspek. (Covid-19, 2020) Hal yang paling nampak nyata adalah prediksi meningkatnya kelompok terdampak, yang juga masuk kelompok warga miskin di Kota Salatiga. Peningkatan jumlah penduduk miskin sudah tentu akan berimplikasi pula kebijakan penganggaran dan perencanaan yang berpihak pada masyarakat tidak mampu (Pro-Poor Budgeting). Di Kota Salatiga, permasalahan yang terjadi adalah meningkatnya jumlah Keluarga Penerima Manfaat (KPM) Kementerian Sosial diverifikasi-validasi oleh Dinas Sosial Kota Salatiga. Peningkatan sebagai akibat dari merebaknya Pandemi Covid-19 membawa konsekuensi yang tidak sedikit, terutama berkaitan dengan aspek kebijakan penganggaran dan perencanaan untuk warga kurang mampu (yang dimanifestasikan melalui DTKS).

Kajian terkait Pro Poor Budgeting sudah pernah diteliti oleh peneliti sebelumnya. Kajian yang dilakukan oleh Harry dengan judul Keberpihakan Kebijakan Anggaran Pemerintah Daerah terhadap Penduduk Miskin: Studi Kasus Anggaran Bidang Kesehatan di Kota Binjai, dimuat dalam jurnal Populasi: Jurnal Kependudukan dan Kebijakan Universitas Gadjah Mada. Penelitian tersebut menguraikan hasil bahwa Pemerintah Kota Binjai belum optimal dalam mengalokasikan anggaran pada bidang kesehatan yang berpihak kepada penduduk miskin. Hal tersebut ditandai walapun Pemerintah Kota Binjai sudah memprioritaskan kebijakan penganggaranya pada bidang kesehatan, akan tetapi alokasi anggaran tidak menunjukkan hal yang demikian yaitu anggaran proporsi kesehatan warga miskin masih kecil. Disparitas dalam penganggaran sektor kesehatan yang berpijak pada warga miskin tersebut antara lain ditemukan dengan adanya pemangkasan anggaran, terutama di unit pelayan teknis seperti Puskesmas di Binjai. Namun demikian meskipun alokasi anggaran tersebut mengalami penurunan akan tetapi kontribusi yang dilakukan Puskesmas tersebut mengalami peningkatan. (Harry, 2009)

Penelitian pada Jurnal Ilmiah Ekonomi Global Masa Kini yang dilakukan oleh Padriansyah dengan judul Analisis Penerapan dan Perkembangan Pro-Poor Budgeting Di Provinsi Sumatera Selatan Tahun 2009-2013. Hasil kajian tersebut yaitu implementasi penganggaran yang berpihak pada warga miskin dengan rasio 0.2 ditahun 2009,2010,2011 di Sumatera Selatan, oleh karena itu mendapat predikat "Sangat Berpihak". Pada tahun 2012 dan 2013 implementasi penganggaran berpihak pada masyarakat miskin dengan rasio 0.18 di Sumatera Selatan dan mendapat predikat kategori 'Cukup Berpihak". Dengan demikian implementasi Pro Poor Budgeting di Sumatera Selatan mengalami penurunan.(Padriyansyah, 2015) Kesamaan dengan yang dikaji oleh peneliti adalah sama-sama menganalisis tentang keberpihakan kebijakan anggaran bagi warga miskin. Kesamaan inilah yang menjadikan penelitian relevan untuk dijadikan rujukan dalam proses penyusunan penelitian. Sedangkan hal yang membedakan dengan penelitian ini meliputi lokasi penelitian, cakupan kebijakan/urusan yang akan dianalisis, periodesasi waktu pelaksanaan, dan kaitan dengan isu global yang sedang terjadi (Pandemi Covid-19).

Penelitian Pengaruh Alokasi Belanja Daerah untuk Urusan Pendidikan, Kesehatan, dan Pekerjaan Umum terhadap Penanggulangan Kemiskinan (Studi Kasus Kabupaten/ Kota di Provinsi Jawa Tengah Tahun 2007-2009) yang dilakukan oleh Wahyudi, kajian tersebut menjelaskan anggaran kesehatan, pendidikan, serta pekerjaan umum berdampak pada pengurangan persentasi warga tidak mampu di Jawa Tengah. Pengaruh terbesar yaitu belanja daerah pada sektor pendidikan, setiap $1 \%$ peningkatan belanja daerah untuk pendidikan terjadi penurunan persentasi warga miskin yaitu $0,304 \%$. Pernyataan tersebut didukung data dari 2 kabupaten sebagai contoh mengindikasikan sebagian besar lebih dari 80\%. (Wahyudi, 2011) Kesamaan yang dengan yang dikaji oleh peneliti adalah sama-sama menganalisis tentang keberpihakan kebijakan anggaran bagi warga miskin. Kesamaan inilah yang menjadikan penelitian 
relevan untuk dijadikan rujukan dalam proses penyusunan penelitian. Sedangkan hal yang membedakan meliputi lokasi penelitian, cakupan kebijakan/urusan yang akan dianalisis, periodesasi waktu pelaksanaan, dan kaitan dengan isu global yang Pandemi Covid-19.

Penelitian dengan judul Analisis Kinerja dan Keberpihakan APBD untuk Rakyat (Studi Kasus Di Kota Madiun Tahun 2004-2008) oleh Nurharibnu Wibisono. Penelitian ini menguraikan bagaimana visi misi Pemerintah Kota Madiun dalam arah kebijakan umum belanja daerah serta work program yang berdasarkan RPJP dan RPJM. Akan tetapidalam implementasinya terindikasi tidak konsisten pada merumuskan prioritas pembangunan daerah, misi, serta program kerja dan arah kebijakan umum anggaran daerah. Indikator kinerja tidak terlihat jelas pada perencanaan pembangunan daerah mengakibatkan sulitnya dalam mengukur keberhasilan program, terutama bagi program yang berpihak pada rakyat. (Wibisono, 2010)

Pandemi Covid-19 sebagai isu global pembangunan membawa dampak yang tidak kecil, terutama bagi kelompok kelompok marginal atau kelompok rentan. Merujuk pada penelitian dari PRAKARSA (2020) kelompok masyarakat marginal menjadi kelompok paling rentan terdampak Covid-19. PRAKARSA menyatakan bahwa multidimensional poverty, serta kelompok risiko, mengindikasikan hubungan antara kelompok terdampak Covid-19 dengan peningkatan kemiskinan. (Thaariq et al., 2020)

Penelitian Analisis Implementasi Pro-Poor Budgeting Pemerintah Kota Salatiga Di Masa Pendemi Covid-19 Tahun 2020 bertujuan untuk menggambarkan atau menjelaskan penerapan Pro-Poor Budgeting di Pemerintah Kota Salatiga saat Covid-19 tahun 2020. Penelitian ini secara praktis dapat digunakan sebagai referensi mekanisme perencanaan dan penganggaran berfokus pada masyarakat tidak mampu. Penelitian ini dianalisis dengan menggunakan teori implementasi kebijakan George Edward III yaitu 4 (empat) aspek kebijakan yang meliputi struktur birokrasi, sumber daya, disposisi, dan komunikasi.(Edwards, 1984)

Merujuk gagasan George Edward tolak ukur pada policy implementation, terdapat 4 aspek dalam implementasi kebijakan antara lain sumber daya, komunikasi, birokraksi serta disposisi. Komunikasi dapat berajlan dengan baik apabila kebijakan yang dijalankan dapat dijelaskan dengan baik. Terkait penyampaian informasi, proses information clarity, informasi yang dibutuhkan untuk pengambilan keputusan dan konsistensi informasi. Sumber daya yaitu staf yang memenuhi secara kuantitas dan kualitas, kewenangan memadai dalam melaksanakan tugas atau tanggung jawab dan fasilitas yang dibutuhkan dalam pelaksanaannya. Disposisi atau sikap pelaksana merupakan komitmen pelaksana terhadap kebijakan penanggulangan kemiskinan. Struktur birokrasi berdasarkan standar prosedur operasional yang mengatur alur kerja sistem dan pelaksanaan kebijakan dalam hal ini pelaksana kebijakan Pro Poor Budgeting oleh Pemerintah Kota Salatiga.

\section{METODE PENELITIAN}

Mengunakan metode deskriptif dengan jenis penelitian kualitatif. Lokasi riset yaitu Pemerintah Kota Salatiga. Teknik pengumpulan data dengan menggunakan trianggulasi yaitu observasi langsung dilapangan, wawancara/diskusi dengan pihak terkait, serta mempelajari dokumen penunjang yang berkaitan dengan perencanaan dan penganggaran terutama program penanggulangan kemiskinan. Data dianalisis dengan menggunakan Teori George Edward III sebagai salah satu teori implementasi kebijakan.

\section{HASIL DAN PEMBAHASAN}

Upaya penanggulangan kemiskinan Pemerintah Kota Salatiga secara khusus tertuang dalam Peraturan Daerah Kota Salatiga Nomor 5 Tahun 2013 Percepatan Penanggulangan Kemiskinan di Kota Salatiga. Sedangkan kebijakan penanggulangan kemiskinan Kota Salatiga tertuang pada Pasal 14 Peraturan Daerah Kota Salatiga Nomor 5 Tahun 2013 tersebut difokuskan 
pada 3 (tiga) arah kebijakan sebagai berikut:

1. Kebijakan untuk meningkatkan kesejahteraan

Kebijakan peningkatan kesejahteraan ditujukan untuk meningkatkan keterjangkauan masyarakat miskin terhadap kebutuhan dasar manusia, termasuk pangan, pendidikan, kesehatan, tempat tinggal, air bersih dan sanitasi, rasa aman, serta guncangan dan bencana sosial. Kemudian mendorong masyarakat miskin untuk meningkatkan pendapatannya dengan menyediakan lapangan kerja dan kesempatan berusaha. Kebijakan untuk meningkatkan kesejahteraan rakyat antara lain:

a. Mewujudkan hak-hak dasar sektor pangan, dengan fokus pemenuhan kebutuhan pangan masyarakat miskin

b. Mewujudkan hak-hak dasar bidang kesehatan, dengan fokus pada penyediaan pelayanan kesehatan dan peningkatan kesehatan masyarakat miskin

c. Menyediakan layanan pendidikan yang berfokus pada pemerataan dan memperluas kesempatan pendidikan bagi masyarakat miskin

d. Mewujudkan pelayanan infrastruktur dasar, khususnya perumahan yang dirancang untuk menyediakan perumahan yang layak bagi masyarakat miskin;

e. Memberikan pelayanan air bersih dan sanitasi bagi masyarakat miskin

f. Tujuan mewujudkan hak atas lingkungan hidup yang lebih sehat adalah untuk memecahkan masalah infrastruktur dan membangun lingkungan hidup dan ruang publik yang lebih sehat bagi masyarakat miskin.

g. Mewujudkan hak atas kesempatan kerja dan berusaha, meningkatkan produktivitas usaha dan produktivitas tenaga kerja, serta mengupayakan dan mendorong upaya ekonomi kreatif

h. Perwujudan hak atas tanah lebih untuk melindungi hak-hak individu dan masyarakat atas tanah yang dimiliki dan ditempati secara layak sesuai dengan peraturan perundang-undangan yang berlaku.

i. Mendapatkan rasa aman dari gangguan keamanan, tindakan kekerasan, goncangan sosial dan bencana, yang bertujuan untuk meningkatkan keamanan dan kenyamanan lingkungan, menciptakan suasana politik yang kondusif, dan sepenuhnya memprediksi atau mengurangi bencana.

2. Kebijakan untuk mengembangkan kemandirian

Melalui berbagai pemberdayaan masyarakat, peningkatan produktivitas dan pengetahuan, mendorong sinergi dan membangun kemitraan dengan semua pihak untuk mempercepat upaya pengentasan kemiskinan di Saratiga, serta mengupayakan kemandirian masyarakat miskin. Uraian kebijakan tersebut meliputi:

a. Peningkatan peran lembaga masyarakat dalam pengentasan kemiskinan dapat mengidentifikasi masalah dan potensi yang ada di masyarakat, serta dapat mempengaruhi proses pengambilan keputusan, termasuk perencanaan, pelaksanaan dan pemantauan kebijakan publik.

b. Menciptakan lingkungan yang menguntungkan bagi upaya produktif masyarakat miskin, bertujuan untuk meningkatkan investasi dalam rangka meningkatkan perekonomian daerah dengan memberikan stimulus yang mendukung, dan untuk menumbuhkan usaha kecil dan menengah yang baru memulai, memiliki potensi, dan mengembangkan.

c. Pemberdayaan perempuan dan perlindungan anak diarahkan pada peningkatan peran perempuan dalam berbagai strata kehidupan dan peningkatan perlindungan terhadap anak.

d. Membangun kemitraan dalam penanggulangan kemiskinan untuk meningkatkan 
keterpaduan pelaksanaan penanggulangan kemiskinan sebagai gerakan ethical dan mendorong tanggung jawab bersama dalam melakukan penanggulangan kemiskinan.

3. Kebijakan mewujudkan masyarakat yang bermartabat

Upaya untuk mewujudkan masyarakat yang bermartabat dilakukan dengan berbagai langkah kebijakan dengan mendorong perilaku, budaya masyarakat menjunjung tinggi moral, religiusitas, memiliki akhlak mulia dan menjunjung tinggi nilai-nilai kemanusiaan, prinsip kemasyarakatan dan menghormati kearifan lokal sehingga mempunyai jati diri dan mampu sejajar dan bersaing dengan daerah lain, langkah-langkah kebijakan yang dilakukan untuk mewujudkan masyarakat yang bermartabat antara lain:

a. Meningkatkan pengamalan kepedulian sosial yang didasari oleh nilai-nilai kemanusiaan, religiusitas dan kesetiakawanan sosial serta prinsip kemasyarakatan

b. Pembenahan sistem kemasyarakatan yang bersih dari budaya Korupsi, Kolusi dan Nepotisme dalam pelaksanaan program penanggulangan kemiskinan

c. Meningkatkan kesadaran dan kepedulian serta tanggung jawab bersama para pemangku kepentingan untuk melakukan gerakan moral penanggulangan kemiskinan.

Strategi utama percepatan penanggulangan kemiskinan diatur dalam Pasal 15 Peraturan Daerah Kota Salatiga Nomor 5 Tahun 2013 tentang Percepatan Penanggulangan Kemiskinan di Kota Salatiga. Adapun strategi tersebut adalah sebagai berikut:

1. Meningkatkan akses terhadap pelayanan dasar, yaitu upaya perbaikan akses masyarakat terhadap pelayanan dasar meliputi: pelayanan pendidikan, kesehatan, air bersih dan sanitasi, pangan dan gizi untuk mengurangi biaya yang harus dikeluarkan oleh Keluarga Miskin dan Penduduk Miskin, serta peningkatan akses terhadap pelayanan dasar yang dapat mendorong pada peningkatan investasi modal manusia (human capital).

2. Memperbaiki program perlindungan sosial, yaitu upaya perbaikan dan pengembangan sistem perlindungan sosial bagi penduduk miskin dan rentan dengan membantu individu dan masyarakat menghadapi goncangan-goncangan (shocks) dalam hidup seperti jatuh sakit, kematian anggota keluarga, kehilangan pekerjaan, ditimpa bencana atau bencana alam dan sebagainya sehingga mereka tidak jatuh miskin.

3. Pemberdayaan kelompok masyarakat miskin, yaitu strategi yang dilaksanakan untuk meningkatkan efektifitas dan keberlanjutan penanggulangan kemiskinan melalui mekanisme atas-bawah (top-down) dengan penyertaan partisipasi masyarakat secara aktif.

4. Menciptakan pembangunan inklusif, yaitu pembangunan yang mengikutsertakan dan sekaligus memberi manfaat kepada seluruh masyarakat. Strategi pembangunan inklusif yang dapat dikembangkan, meliputi: upaya peningkatan pertumbuhan ekonomi yang dapat memberikan efek multiplier pada peningkatan pendapatan mayoritas penduduk, peningkatan taraf hidup, dan pengurangan angka kemiskinan.

Untuk mempermudah implementasi bagi OPD, strategi utama tersebut dituangkan dalam Strategi Penanggulangan Kemiskinan Daerah (SPKD) yang dijabarkan dalam program percepatan penanggulangan kemiskinan. SPKD adalah dokumen strategi penanggulangan kemiskinan daerah yang selanjutnya digunakan sebagai rancangan kebijakan pembangunan daerah di bidang penanggulangan kemiskinan dalam proses penyusunan Rencana Pembangunan Jangka Menengah Daerah (RPJMD). Dengan demikian, SPKD menjadi acuan bagi lintas pelaku dan lintas sektor dalam pengoordinasian pelaksanaan program percepatan penanggulangan kemiskinan. SPKD ditetapkan dengan Peraturan Walikota dan disusun memuat hal-hal sebagai berikut:

1. Strategi utama percepatan penanggulangan kemiskinan. 
2. Target-target peningkatan kesejahteraan yang dirumuskan dalam RPJMD.

3. Analisis kondisi dimensi-dimensi kemiskinan untuk menentukan prioritas perencanaan program percepatan penanggulangan kemiskinan.

4. Analisis penganggaran program percepatan penanggulangan kemiskinan agar menghasilkan anggaran yang efektif untuk penanggulangan kemiskinan.

5. Analisa dan mekanisme pengendalian progrm percepatan penanggulangan kemiskinan.

SPKD Kota Salatiga disusun pada tahun 2011 dan telah direview pada tahun 2013 serta ditetapkan dengan Peraturan Walikota Salatiga Nomor 18 Tahun 2013. Namun demikian Strategi Penanggulangan Kemiskinan di Kota Salatiga belum tercantum dalam dokumen SPKD. Oleh karena itu strategi yang ditempuh masih mengacu sepenuhnya pada Peraturan Presiden Nomor 15 Tahun 2010 tentang Percepatan Penanggulangan Kemiskinan, yaitu:

1. Mengurangi beban pengeluaran masyarakat miskin dengan mengurangi beban kebutuhan dasar seperti akses pada pendidikan, kesehatan dan pembangunan infrastruktur kegiatan sosial ekonomi maupun pengelolaan ekonomi rumah tangga secara efektif untuk efisiensi pengeluaran dan konsumsi.

2. Meningkatkan kemampuan dan pendapatan masyarakat miskin melalui peningkatan produktivitas, dimana masyarakat memiliki kemampuan pengelolaan, memperoleh peluang dan perlindungan untuk memperoleh hasil yang lebih baik dalam berbagai kegiatan ekonomi, sosial budaya maupun politik.

3. Mengembangkan dan menjamin keberlanjutan usaha mikro dan kecil dilakukan dengan mewujudkan iklim usaha dan investasi yang kondusif dan menyediakan sumber-sumber pembiayaan bank dan nonbank yang dijamin oleh pemerintah, memperkuat kemandirian berusaha, memberi dukungan positif dan nyata terhadap pengembangan sumber daya manusia (pelatihan kewirausahaan), teknologi, informasi, akses pendanaan serta pemasaran.

4. Mensinergikan kebijakan dan program penanggulangan kemiskinan yaitu dengan Koordinasi kebijakan dan program penanggulangan kemiskinan untuk menyelaraskan langkah-langkah yang dilakukan pemerintah dan pemangku kepentingan dalam setiap keputusan yang berkaitan dengan penanggulangan kemiskinan, sehingga dalam pelaksanaan program, tidak mengalami benturan atau inkonsitensi antara satu kebijakan dengan kebijakan lainnya.

Pemerintah mengkonsolidasikan program-program penanggulangan kemiskinan menjadi 4 (empat) kelompok program penanggulangan kemiskinan yang terdiri dari:

a. Program Bantuan Sosial Terpadu Berbasis Keluarga yang bertujuan untuk melakukan pemenuhan hak dasar, pengurangan beban hidup, dan perbaikan kualitas hidup masyarakat miskin.

b. Program Penanggulangan Kemiskinan Berbasis Pemberdayaan Masyarakat yang bertujuan untuk mengembangkan potensi dan memperkuat kapasitas kelompok masyarakat miskin untuk terlibat dalam pembangunan yang didasarkan pada prinsip-prinsip pemberdayaan masyarakat.

c. Program Penanggulangan Kemiskinan Berbasis Pemberdayaan Usaha Ekonomi Mikro dan Kecil yang bertujuan untuk memberikan akses dan penguatan ekonomi bagi pelaku usaha berskala mikro dan kecil.

d. Program-program lainnya baik yang secara langsung maupun tidak langsung dapat meningkatkan kegiatan ekonomi dan kesejahteraan masyarakat miskin 
Alokasi dana program penanggulangan kemiskinan (Pro Poor Budgeting) Kota Salatiga tahun 2019 sebesar Rp.117.242.275.000,- atau 10,08\% dari total APBD tahun 2019 yaitu sebesar Rp.1.162.667.248.000,-). Alokasi anggaran untuk program penanggulangan kemiskinan (Pro Poor Budgeting) tersebut berasal dari APBN, APBD Provinsi Jawa Tengah, APBD Kota Salatiga dan DBHCHT, dengan rincian dilihat pada tabel dan diagram berikut:

Tabel 1. Anggaran Program Penanggulangan Kemiskinan Tahun 2019

\begin{tabular}{|l|l|r|c|}
\hline No & \multicolumn{1}{|c|}{ Sumber Dana } & \multicolumn{1}{c|}{ Jumlah $(\mathrm{Rp})$} & Prosentase $(\%)$ \\
\hline 1. & APBN & $48.290 .566 .000,-$ & 41,19 \\
\hline 2. & APBD Provinsi Jawa Tengah & $3.993 .000 .000,-$ & 3,41 \\
\hline 3. & APBD Kota Salatiga & $65.432 .204 .000,-$ & 54,31 \\
\hline 4. & DBHCHT & $1.288 .505 .000,-$ & 1,10 \\
\hline
\end{tabular}

Sumber: Bappeda Kota Salatiga, 2019

Pro Poor Budgeting Kota Salatiga tahun 2019 sebesar Rp.117.242.275.000,- terbagi dalam 4 kelompok program penanggulanganan kemiskinan, yaitu Kelompok Program Bantuan Sosial Terpadu Berbasis Keluarga dan Individu, Kelompok Program Penanggulangan Kemiskinan Berbasis Pemberdayaan Masyarakat, Kelompok Program Penanggulangan Kemiskinan Berbasis Pemberdayaan Usaha Ekonomi Mikro dan Kecil, dan Kelompok Program Lainnya. Distribusi anggaran per kelompok program adalah sebagai berikut:

a. Kelompok Program Bantuan Sosial Berbasis Rumah Tangga sebesar Rp.18.306.575.000,dengan OPD pengampu terdiri dari Dinas Kesehatan; Dinas Pendidikan; dan Dinas Sosial. Terlihat dalam diagram berikut ini:

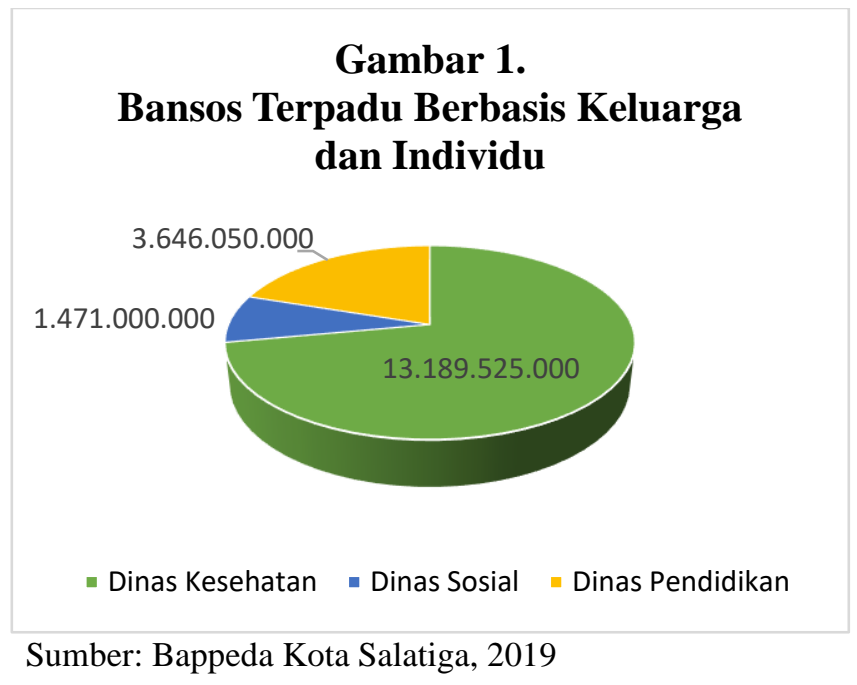

b. Kelompok Program Pemberdayaan Masyarakat sebesar Rp. 2.223.396.000,- dengan OPD pengampu adalah Dinas Perindustrian dan Tenaga Kerja, Kecamatan Sidorejo, Dinas Persip, Kecamatan Argomulyo, Kecamatan Sidomukti dan Dinas Budpar. Terlihat dalam diagram berikut: 


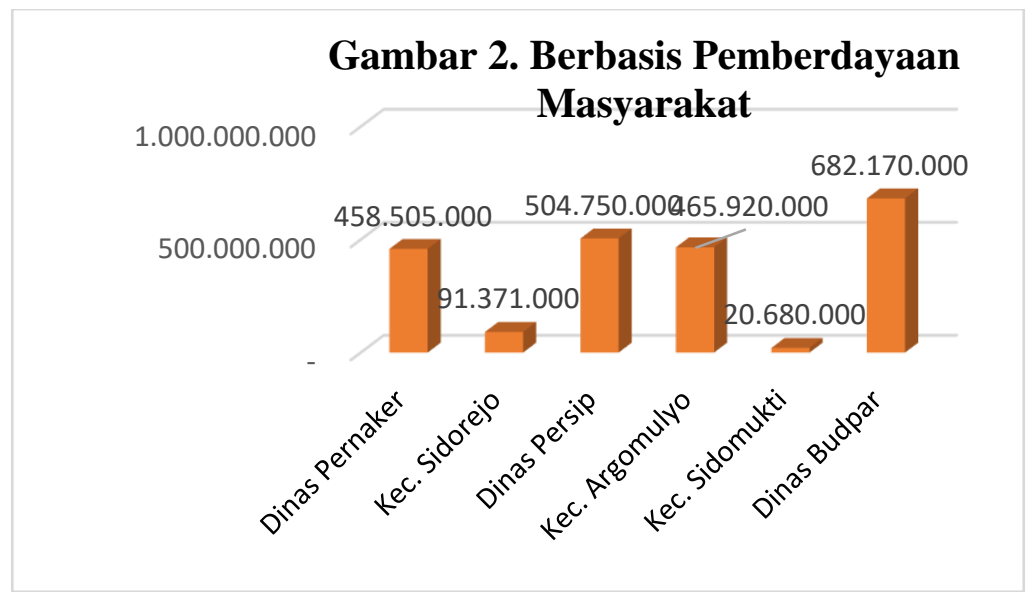

Sumber: Bappeda Kota Salatiga, 2019

c. Kelompok Program Pemberdayaan Usaha Ekonomi Mikro Kecil sebesar Rp.1.021.000.000,dengan OPD pengampu adalah Dinas Koperasi dan UKM, Dinas Perdagangan dan Bappeda. Anggaran yang 0,87\% dari anggaran Program Penanggulangan Kemiskinan Tahun 2019, anggaran ini masih terlalu kecil untuk pengembangan usaha kecil menengah. Selanjutnya tertuang dalam diagram berikut:

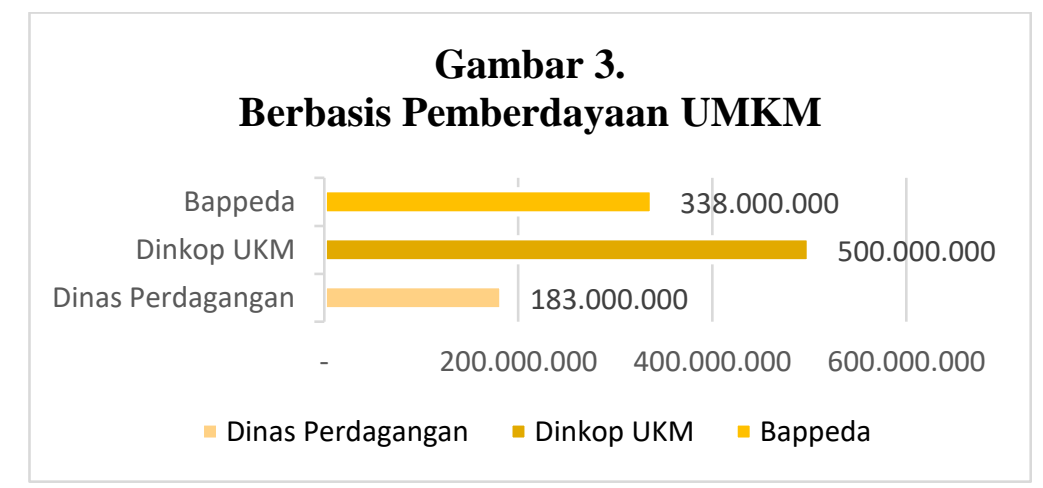

Sumber: Bappeda Kota Salatiga, 2019

d. Kelompok Program Lainnya sebesar Rp.95.691.304.000,- dengan OPD pengampu adalah Dinas Kesehatan, Dinas PKP, Dinas Pangan, Kecamatan Sidorejo, Dinas Pendidikan, DP3A, Dinas Pertanian, DPUPR, Dinas Lingkungan Hidup, Dinas Kependudukan dan Catatan Sipil, Dinas Pengendalian Penduduk dan KB dan Kecamatan Sidomukti. Selanjutnya tertuang dalam gambar berikut:

\section{Gambar 4}

Kelompok Program Lainnya 


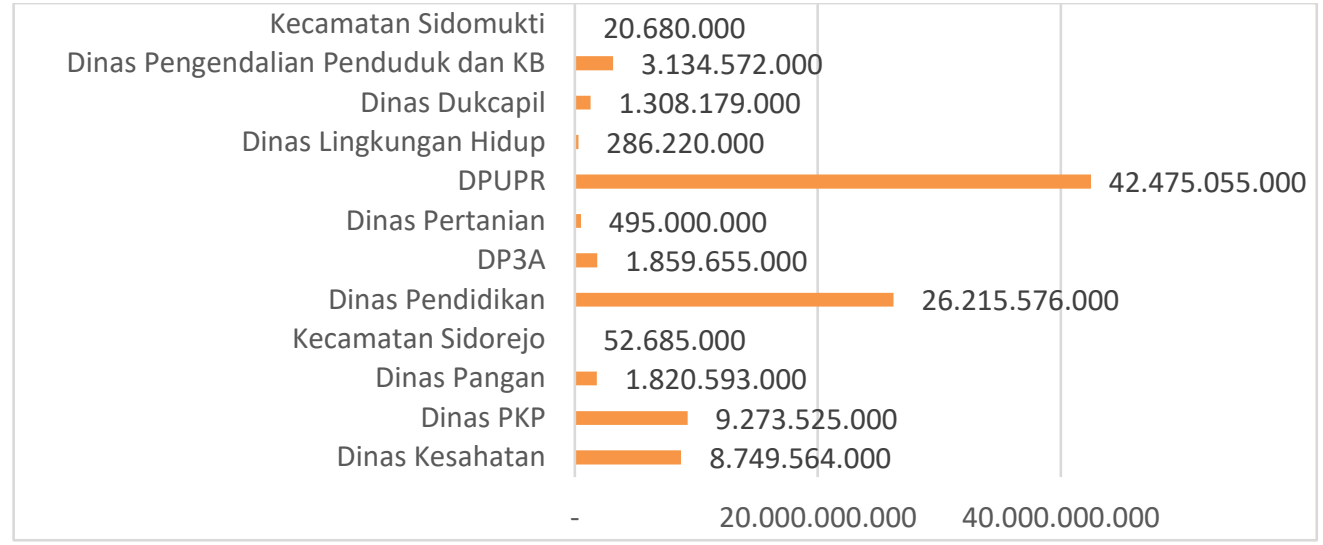

Sumber: Bappeda Kota Salatiga, 2019

\section{Refocusing Anggaran dan Pro Poor Budgeting di Masa Pandemi Covid-19}

Awal tahun 2020 dengan ditetapkannya kondisi gawat darurat nasional dikarenakan adanya pandemi Covid-19 serta dikeluarkannya berbagai kebijakan pemerintah dalam penanganan Covid19 dari aspek ekonomi dan sosial, pengelolaan keuangan daerah, sampai dengan pembatasan aktifitas masyarakat, berpengaruh pada pencapaian target kinerja pemerintah daerah. Berdasarkan Instruksi Presiden No 4 Tahun 2020 tentang Refocusing Kegiatan, Realokasi Anggaran, serta Pengadaan Barang dan Jasa dalam Rangka Percepatan Penanganan Covid-19, serta berdasarkan Surat Keputusan Bersama Menteri Keuangan dan Menteri Dalam Negeri tentang Percepatan Penyesuaian APBD Tahun 2020 dalam Rangka Penanganan Covid-19 serta Pengamanan Daya Beli Masyarakat dan Perekonomian Nasional, maka telah dilakukan perubahan APBD Tahun 2020 sebanyak 6 kali terakhir dengan diterbitkannya Peraturan Walikota Salatiga Nomor 19 Tahun 2020 tanggal 8 Juli 2020 tentang Perubahan Ke-enam atas Peraturan Walikota Nomor 42 Tahun 2019 tentang Penjabaran Anggaran Pendapatan dan Belanja Daerah Tahun 2020. Sehingga perubahan RKPD Tahun 2020 didasarkan pada Perubahan ke-6 APBD Tahun 2020.

Refocusing kegiatan dan realokasi anggaran yang dilakukan pada APBD tahun 2020 untuk penanganan Covid-19 di Kota Salatiga dengan mengalihkan anggaran belanja langsung Perangkat Daerah ke dalam belanja tidak terduga sebesar 53 milyar dan refocusing kegiatan Perangkat Daerah untuk penanganan Covid 19 sebesar 18 milyar rupiah, sehingga total anggaran yang digunakan untuk penanganan Covid 19 sebesar 71 milyar rupiah. (Salatiga et al., 2020)

Penyebaran wabah COVID-19 telah membuat pemerintah di seluruh dunia mengeluarkan kebijakan untuk membatasi aktivitas di luar rumah. Kebijakan tersebut berdampak kuat pada keseimbangan internal maupun keseimbangan eksternal seluruh negara.

Kebijakan tersebut secara makro merupakan kebijakan tindaklanjut atas kebijakan nasional berkaitan dengan penanganan dampak Covid-19, terutama untuk program dampak kesehatan, dampak ekonomi, maupun pnguatan jaringan pengaman sosial. Dari ketiga dampak tersebut, dua dampak terakhir berkaitan erat dengan warga tidak mampu. Dalam titik inilah yang menjadi pijakan dalam arah kebijakan Pro Por Budgeting Kota Salatiga di masa Pandemi Covid.

Berdasarkan analisis terhadap indikator makro ekonomi Salatiga pada masa pandemi Covid 19 dan memperhatikan kondisi ekonomi Jawa Tengah, nasional maupun global, maka arah pembangunan ekonomi Kota Salatiga Tahun 2020 pada semester II diprioritaskan pada penanganan bidang kesehatan, jaring pengaman ekonomi dan jaring pangaman sosial. Sisi jaring pengaman ekonomi diharapkan dapat memberikan kontribusi terhadap PDRB yaitu sektor tersier, sektor yang 
memiliki prospek yang baik serta tahan terhadap guncangan ekonomi, sedangkan sektor lainnya sebagai pendukung.

Dalam rangka mencapai pertumbuhan ekonomi agar tidak tumbuh secara negatif dan sesuai dengan target yang telah direncanakan, serta dengan memperhatikan kondisi perekonomian worldwide dan nasional, kebijakan ekonomi Kota Salatiga diarahkan pada peningkatan perekonomian daerah berbasis potensi unggulan daerah dengan penerapan protokol kesehatan menghadapi Tatatan Ordinary Baru Produktif dan Aman Covid-19, sehingga pertumbuhan ekonomi yang tetap dapat meningkat walaupun belum sesuai dengan target yang akan dicapai. Langkah dan upaya yang dilakukan antara lain melalui:

1. Mendorong program pemberdayaan ekonomi untuk meningkatkan permintaan terutama untuk penanganan ekonomi pada masa pandemi Covid-19

2. Konektivitas antara pusat pertumbuhan ekonomi tinggi dengan rendah dengan meningkatkan kualitas dan ketersediaan infrastruktur yang semakin baik sebagai upaya mendorong permintaan pasar

3. Meningkatkan daya saing produk UMKM/IKM berbahan baku lokal dengan memanfaatkan inovasi dalam proses produksi dan pemasaran

4. Peningkatan akses pasar dan promosi bagi potensi unggulan di daerah melalui media sosial dan berbasis online

5. Peningkatan iklim usaha kondusif terutama bagi investasi yang menyerap tenaga kerja yang mendukung ekonomi kerakyatan dan mengatasi pengangguran sebagai akibat PHK

6. Peningkatan kelancaran arus distribusi barang kelompok kebutuhan masyarakat dan barang strategis serta kelompok jasa

\section{Pro-Poor Budgeting Kota Salatiga di Masa Pandemi Covid-19 Tahun 2020}

Kondisi kemiskinan Masa Pandemi Covid-19 maupun arah kebijakan penganggaran Kota Salatiga melalui refokusing anggaran berimplikasi pada arah penganggaran untuk program penanggulangan kemiskinan. Implikas tersebut berkaitan dengan pergeseran prioritas program penangulangan kemiskinan tahun 2020, total alokasi dana program penanggulangan kemiskinan sebesar Rp.106.991.336.500,- dengan rincian sebagai berikut.

Tabel 2.Alokasi Anggaran Untuk Kemiskinan (Pro Poor Budgeting) Kota Salatiga Tahun 2020 (Berdasarkan Sumber Pembiayaan)

\begin{tabular}{|l|l|r|r|}
\hline No & \multicolumn{1}{|c|}{ Sumber Dana } & \multicolumn{1}{c|}{ Jumlah } & \multicolumn{1}{c|}{ Prosentase } \\
\hline 1. & APBN & 37.184 .477 .400 & $34,75 \%$ \\
\hline 2. & APBD Provinsi Jawa Tengah & 3.332 .977 .000 & $3,12 \%$ \\
\hline 3. & APBD Kota Salatiga & 65.243 .603 .100 & $60,98 \%$ \\
\hline 4. & DBHCHT & 1.230 .279 .000 & $1,15 \%$ \\
\hline
\end{tabular}

Sumber: Bappeda Kota Salatiga, 2020

Alokasi dan realisasi anggaran program penanggulangan kemiskinan tahun 2020 sebesar Rp.35.119.479.864,- tersebar di 17 OPD, sebagaimana tertuang dalam tabel berikut 
Tabel 3. Sebaran Pro Poor Budgeting Kota Salatiga Tahun 2020 Berdasarkan Kelompok Program dan Perangkat Daerah Pengampu

\begin{tabular}{|c|l|c|l|}
\hline No. & \multicolumn{1}{|c|}{ Pokgram } & Alokasi Dana (Rp.) & \multicolumn{1}{c|}{ OPD } \\
\hline 1 & $\begin{array}{l}\text { Bantuan Sosial } \\
\text { Berbasis } \\
\text { Keluarga }\end{array}$ & 29.849 .554 .000 & $\begin{array}{l}\text { Dinas Pangan, Dinas Pendidikan, } \\
\text { Dinas Perumahan dan Kawasan } \\
\text { Permukiman, Dinas Kesehatan, } \\
\text { Dinas Sosial, Kecamatan Tingkir }\end{array}$ \\
\hline 2 & $\begin{array}{l}\text { Pemberdayaan } \\
\text { Masyarakat }\end{array}$ & 702.745.000 & $\begin{array}{l}\text { Dinas Perindustrian dan Tenaga } \\
\text { Kerja, Dinas Perpustakaan dan } \\
\text { Kearsipan }\end{array}$ \\
\hline 3 & $\begin{array}{l}\text { Pemberdayaan } \\
\text { UMKM }\end{array}$ & 2.134 .960 .000 & $\begin{array}{l}\text { Dinas Koperasi, Usaha Kecil dan } \\
\text { Menengah, Bappeda, Dinas } \\
\text { Perdagangan }\end{array}$ \\
\hline 4 & $\begin{array}{l}\text { Pendukung } \\
\text { Lainnya }\end{array}$ & $\begin{array}{l}\text { Dinas Pengendalian Penduduk dan } \\
\text { Keluarga Berencana, Dinas Pangan, } \\
\text { Dinas Pendidikan, Dinas } \\
\text { Pemberdayaan Perempuan dan } \\
\text { Perlindungan Anak, Dinas } \\
\text { Lingkungan Hidup, Dinas } \\
\text { Pertanian, Dinas Pekerjaan Umum, } \\
\text { Dinas Kesehatan, Dinas } \\
\text { Kebudayaan dan Pariwisata }\end{array}$ \\
\hline & 74.304.077.500 \\
\hline
\end{tabular}

Sumber: Bappeda Kota Salatiga, 2020

Selain itu sebagaimana fokus anggaran untuk penanganan dampak Covid-19, alokasi anggaran tertuang dalam tabel berikut.

Tabel 4. Sebaran Fokus Anggaran Berdasarkan Prioritas Dampak Covid-19 Kota Salatiga Tahun 2020

\begin{tabular}{|c|l|l|l|}
\hline No & \multicolumn{1}{|c|}{ Fokus } & \multicolumn{1}{c|}{ Pagu Anggaran (Rp) } & \multicolumn{1}{c|}{ Keterangan } \\
\hline 1 & Kesehatan & Rp. 45.806.936.750 & $\begin{array}{l}\text { Dengan BTT sebesar. } \\
14.006 .600\end{array}$ \\
\hline 2 & $\begin{array}{l}\text { Pemulihan } \\
\text { Ekonomi/Penanganan } \\
\text { Dampak Ekonomi }\end{array}$ & Rp. 16.877.235.000 & $\begin{array}{l}\text { Dengan BTT sebesar } \\
\text { Rp. 13.512.417.000 }\end{array}$ \\
\hline 3 & $\begin{array}{l}\text { Jaring Pengaman } \\
\text { Sosial (Social Safety } \\
\text { Net) }\end{array}$ & Rp. 27.536.717.000 & $\begin{array}{l}\text { Dengan BTT sebesar } \\
\text { 25.988.846.000 }\end{array}$ \\
\hline \multicolumn{2}{|c|}{ Total } & Rp. 90.220.888.750 & \\
\hline
\end{tabular}

Sumber: Bappeda Kota Salatiga, 2020 
Selaras dengan prinsip dalam penentuan penganggaran untuk penanggulangan kemiskinan maka anggaran bagi warga miskin baik yang merujuk pada program penanggulangan kemiskinan tahun 2020, maupun dikaitkan ketiga program prioritas anggaran bagi warga terdampak Covid-19 yang berpotensi memunculkan kelompok miskin baru, proses penangggaran bagi program penanngulangan kemiskinan sudah memperhatikan prinsip-prinsip dalam Pro Poor Budgeting, sebagai berikut:

1. Sasaran adalah warga/kelompok miskin

Pro Poor Budgeting ditujukan kepada masyarakat miskin maupun warga terdampak Covid-19 yang secara tidak langsung mempunyai potensi menjadi warga miskin. Hal ini sejalan dengan prinsip Pro Poor Budgeting

2. Fokus pada akar masalah kemiskinan

Pemerintah mengeluarkan kebijakan yang memfokuskan pada 3 hal yaitu perlindungan kesehatan, penanganan dampak ekonomi, maupun penguatan jaringan pengaman sosial. Ketiga prioritas selanjutnya juga menjadi fokus dalam penanganan dampak Covid-19 di Kota Salatiga, termasuk dikaitkan dengan anggaran yang ditujukan bagi kelompok terdampak dan warga miskin.

Dengan demikian maka anggaran yang berpihak pada warga miskin terdampak Covid19 dirumuskan sebagai berikut

1. Memaksimal manfaat bagi orang miskin

Penguatan program penanggulangan kemiskinan melalui Pro Poor Budgeting di masa pandemi merujuk pada akar permasalahan penyebab kemiskinan. Kemanfaatan tersebut didasarkan pada data yang dimilik oleh Pemerintah Kota Salatiga, baik DTKS maupun masyarakat/kelompok terdampak Covid-19 yang dimiliki oleh masing-masing Perangkat Daerah, setelah dilakukan validasi dan verifikasi.

2. Melibatkan partisipasi/peran serta warga miskin

Proses keterlibatan warga miskin atau kelompok terdapak diawali dalam proses musrenbang, meskipun keterlibatan dalam proses tersebut tidak dilakuan secara langsung. Keterlibatan juga dilakukan oleh aparatus ditingkat lokal (kelurahan) maupun pengurus RT/RW terutama dalam proses pendataan masyarakat terdampak dan usulan program yang relevan dengan kebutuhan masyarakat terdampak.

\section{Analisis Implementasi Pro-Poor Budgeting Kota Salatiga di Masa Pandemi Covid Tahun 2020}

Implementasi Pro Poor Budgeting dapat dilihat dalam 2 Perspektif, yaitu implementasi dikaitkan dengan prinsip perencanaan dan penganggaran secara umum maupun implementasi Pro Poor Budgeting sebagai sebuah kebijakan publik. Terkait dengan implementasi proses perencanaan penganggaran secara umum, Pro Poor Budgeting di Kota Salatiga meskipun dilakukan dalam situasi darurat akan tetapi merujuk pada prinsip perencanaan dan penganggaran yaitu:

1. Transparan

Proses perencanaan penganggaran yang ditandai dengan keterbukaan informasi alokasi anggaran untuk penanggulangan kemiskinan, termasuk mereka yang menjadi kelompok sasaran dari program penangguangan kemiskinan. Dokumen anggaran sudah dapat juga diakses oleh publik. Transparansi juga dilakukan dengan dibukanya akses publik dalam proses perumusan program dan kegiatan melalui Musrenbang, sedangkan di masa pandemi Covid-19, partisipasi publik dilakukan melalui tahapan proses pendataan 
warga/kelompok terdampak yag berpotensi menjadi penyebab munculnya warga miskin baru.

2. Rasional

Data aktual dimasa Pandemi Covid-19 dilakukan dengan jelas dan terukur, terutama didasarkan pada akuntabilitas data aktual yang ada di Kota Salatiga. Rasionalitas tersebut ditandai dengan adanya perhitungan yang terukur serta ditindaklanjut dengan terbitnya beberapa regulasi berbentuk Peraturan Walikota yang berisi tentang perubahan APBD sebagai salah satu bentuk komitmen terkiat refokusing anggaran di masa pandemi Covid19

3. Akuntabel

Akuntabilitas ditandai dengan kejelasan prosedur penyusunan anggaran maupun dalam proses akuntablitas data yang digunakan, terutama data yang berkiatan dengan warga/kelompok masyarat terdampak, termasuk data sekotr UKM terdampak pandemi Covid-19. mekansime prosedur pertanggungjawaban pengelolaan anggaran/keuangan yang mendapatkan supervisi dari Perangkat Daerah yang berwenang seperti Inspektorat dan Badan Keuangan Daerah.

4. Keadilan dan Proporsional

Alokasi anggaran pada bidang tertentu yang mendesak berdasarkan kepentingan masyarakat, serta bentuk bantuan pemerintah pada warga miskin dalam menurunkan income inequality menyebabkan ekonomi yang timpang.

Implementasi kebijakan publik George C. Edward III berusaha menjawab dengan mengkaji empat aspek dari kebijakan yaitu struktur birokrasi, sumber daya, disposisi, dan komunikasi. Terkait dengan hal tersebut, maka analisis implementasi Kebijakan Pro Poor Budgeting di Kota Salatiga dengan pendekatan George Edward III dapat pula didekati melalui (empat) faktor tersebut yang diurakan sebagai berikut:

Aspek Struktur Birokrasi. Kebijakan refokusing anggaran ditandai dengan perubahan alokasi penganggaran untuk program penanggulangan kemiskinan telah dilakukan dengan melibatkan berbagai organisasi. Struktur organisasi Pemerintah Kota Salatiga dimanifestasikan melalui struktur organisasi Perangkat Daerah telah menggambarkan tingkatan kewenangan masingmasing baik dari tingkat kota, maupun tingkat Perangkat Daerah, bahkan sampai pada tingkat kelurahan (sebagai unit kerja bagian dari kecamatan). Struktur organisasi nampak dari pembagian kewenangan dalam penentuan kelompok penerima manfaat atau kelompok mitra binaan dari masing masing Perangkat Daerah. Penentuan dilakukan oleh Perangkat daerah yang tertentu dengan selanjutnya dilakukan verifikasi oleh Dinas Komunikasi dan Informatika. Penentuan kelompok sasaran atau mitra binaan antara lain: (1) Mitra Binaan Dinas Lingkungan Hidup adalah mereka yang bertugas sebagai tenaga kebersihan penyapu jalan dan tenaga pengangkut sampah; (2) Mitra Binaan Dinas Perhubungan adalah sopir angkutan umum, maupun juru parkir; (3) Mitra Binaan dari Dinas Perdagangan yaitu PKL dan pedangan di pasar tradisional; (4) Mitra Binaan Dinas Koperasi dan UKM yang terdampak Covid-19. Implementasi Pro Poor Budgeting di masa pandemi Covid-19 disertai dengan pembuatan alur kerja dan bussines process serta Standar Operasional Prosedur (SOP) dalam proses pengusulan kelompok penerima manfaat, pengusulan dana, tranparansi laporan pelaksanaan kegiatan penerima manfaat.

Hal ini menunjukkan bahwa dalam pelaksanaan program penanggulangan kemiskinan, faktor akuntabilitas dalam tata kelola organisasi menjadi kunci dari keberhasilan pelaksanaan program, khususnya implementasi Program Penanggulangan Kemiskinan. Keberhasilan implementasi program penanggulangan kemiskinan di masa pendemi Covid-19 juga ditentukan oleh keterpaduan 
pelaksanaan antara Perangkat Daerah, terutama alokasi anggaranya berkaitan degan kelompok masyarakat marjinal terdampak Covid-19. Upaya sinkronisasi program penanggulangan kemiskinan bagi warga terdampak Covid-19 tidak hanya berkaitan dengan alokasi anggaran dan kelompok sasaran yang berkaitan dengan mitra binaan Perangkat Daerah, akan tetapi juga berkaitan dengan ketersediaan data terpadu yang diampu oleh Kementerian Sosal dan Dinas Sosial Kota Salatiga. Program Pro Poor Budgeting di masa pandemi, secara langsung dirumuskan oleh Satgas Covid-19 Kota Salatiga.

Aspek Sumber Daya. Kebijakan Penanggulangan Kemiskinan dari aspek Sumberdaya mencakup sumberdaya manusia maupun sarana prasarana pendukung lainnya. Terkait dengan aspek sumberdaya terdapat beberapa hal yang dapat diuraikan sebagai berikut

a. Information. Informasi berkaitan dengan sumber dan mekanisme penyampaian informasi yang dilakukan secara berjenjang maupun secara horisontal oleh semua actor yang berkaitan dengan Program Penanggulangan Kemiskinan terutama informasi yang berkaitan dengan data, kelompok sasaran, maupun alokasi anggaran bagi program penanggulangan kemiskinan. Pembagian peran para aktor dalam penyampaian informasi tersebut nampak dari proses dan pemberian informasi melalui berbagai media, baik media formal seperti pada saat pertemuan kelompok, ataupun pertemuan instansi, namun juga melalui media/forum informal. Terkait dengan mekanisme dan model penyampaian informasi inilah yang tidak dapat dilepaskan dari peran masing-masing Perangkat Daerah, baik yang tergabung dalam Satgas Covid-19 maupun dalam Tim Koordinasi Penanggulangan Kemiskinan (TKPK) Kota Salatiga.

b. Materiil. Dapat dilihat dari proses perkembangan ketersediaan data dan anggaran yang mendukung program penangulangan kemiskinan dimasa pandemi. Data alokasi anggaran tersebut meliputi 4 kelompok program dalam program penanggulangan kemiskinan maupun alokasi anggaran melalui Bantuan Tidak Terduga (BTT) bagi kelompok masyarakat terdampak Covid-19 di Kota Salatiga.

c. Perlengkapan dan Peralatan. Berkaitan pada perlengkapan, peralatan yang digunakan oleh penerima manfaat maupun oleh Perangkat Daerah yang mempunyai mitra binaan kelompok terdampak. Selain itu juga perlengkapan dan peralatan yang digunakan oleh Dinas Sosial yang secara khusus mengoordinasikan bantuan kepada masyarakat, termasuk juga komunikasi dan informasi yang berperan dalam melakukan verifikasi data masyarakat terdampak diluar DTKS sebelum mendapatkan intervensi program bantuan bagi masyarakat terdampak sesuai dengan usulan dari masyarakat maupun dari beberapa dinas di lingkup Pemerintah Kota Salatiga. Dalam implementasi Pro Poor Budgeting Kota Salatiga hal tersebut nampak dalam tahap inventarisasi data di selutuh kelurahan maupun data dari kelompok masyarakat terdampak. Tahap identifikasi mulai dilakukan pada Bulan April 2020 dengan melakukan identifikasi terhadap kelompok terdampak maupun pemetaan terhadap program penanggulangan kemiskinan secara umum.

d. Facilitation. Dilakukan oleh pengelola program penanngulangan kemiskinan di berbagai Perangkat Daerah (PFD) di Kota Salatiga, maupun Perangkat Daerah pengelola Program Penanggulangan Kemiskinan., maupun Perangkat Daerah yang mempunyai mitra binaan terdampak Covid-19. Fasilitas yang diberikan antara lain melalui pendampingan dalam proses pendataan dengan melibatkan TKSK yang dikoordinasikan oleh Dinas Sosial maupun oleh aparatur pemerintah di tingkat basis yaitu kelurahan dengan melibatkan pengurus RW dan RT di lingkup Kota Salatiga. Selain itu pendampingan juga melibatkan tenaga Pendamping PKH maupun TKSK. Tujuan fasilitasi adalah agar penerima manfaat akan meningkat kapasitasnya, baik kapasitas individu maupun kapasitas kelompok. Untuk 
meningkatkan pelaksanaan program penanggulangan kemiskinan terutama bagi masyarakat dan kelompok yang terdampak Covid-19 langkah riil yang dapat dilakukan adalah memberikan materi penyuluhan yang sesuai dengan kebutuhan anggota kelompok afinitas sehingga persepsi anggota kelompok dapat meningkat. Selain itu, penyuluh juga dapat berperan sebagai fasilitator yang menjembatani anggota kelompok afinitas untuk memperoleh informasi dari intansi lain yang masih terkait dengan kebutuhan informasi yang dibutuhkan oleh anggota kelompok afinitas.

e. Money. Dukungan alokasi anggaran yang mencukupi merupakan salah satu langkah dalam upaya penanggulangan kemiskinan di masa pandemi. Terutama bagi warga dan kelompok terdampak Covid-19. Alokasi anggaran penanagulangan kemiskinan di masa pandemi Covid-1 disesuaikan dengan alokasi anggaran bagi warga dan kelompok masyarakat terdampak Covid-19.

f. Peoples. Faktor masyarakat merupakan salah satu hal yang utama dalam aspek sumberdaya. Hal tersebut nampak bahwa kapasitas dasar masyarakat menjadi tolok ukur keberhasilan program. Salah satu parameter dari perubahan kapasitas masyarakat adalah dari perubahan pola pikir. Dampak Pro Poor Budgeting di masa terhadap perubahan pola pikir rumah tangga miskin peserta program positif, cukup nyata pada kesadaran berkelompok, pendidikan, kesetaraan gender serta bantuan permodalan, dan juga pada aspek aplikasi teknologi, pemanfaatan sumberdaya, maupun kepercayaan diri dalam kegiatan produktif yang ditandai dengan munculnya inovasi dalam usaha yang dijalankan oleh kelompok usaha kecil yang semula terdampak Covid-19.

Aspek Disposisi. Disposisi berkaitan dengan pembagian kewenangan atau pembagian peran dan juga bahkan daat diikuti dengan pemberian insentif bagi pelaksana di lapangan sebagai ujung tombak implmementasi kebijakan. Terdapat 2 (dua) area dalam aspek disposisi, sebagai berikut:

a. Pengangkatan birokrasi dan pembagian peran. Pembagian peran melalui distribusi keweanngan dalam pelaksanaan kebijakan menjadi kunci bagi keberhasilan implementasi kebijakan tersebut, dimana pengangkatan dan pemilihan personel pelaksana kebijakan haruslah orang-orang yang memiliki dedikasi pada kebijakan yang telah ditetapkan, lebih khusus lagi pada kepentingan warga masyarakat. Oleh karena itu perlu dilakukan dalam bentuk kelembagaan forum koordinasi maupun personil sebagai tenaga lapang. Dalam implementasi kebijakan tersebut di Kota Salatiga ditunjukkan melalui pembagian peran antara pelaksana Pro Poor Budgeting, baik ditingkat Kota Salatiga, masing-masing Perangkat Daerah, Tim Koordinasi Penanggulangan Kemiskinan (TKPK) Kota Salatiga, maupun sampai dengan peran dari tenaga pendamping masyarakat baik TKSK maupun Pendamping $\mathrm{PKH}$, dan juga nampak melalui kelompok-kelompok penerima manfaat yang ada (antara lain kelompok afinitas).

b. Insentif. Pada dasarnya orang bergerak tentunya juga berkaitan erat dengan kepentingan dan pemeuhuan kebutuah hidupnya, maka pemberian insentif terutama bagi petugas lapang atau tenaga pendamping masyarakat menjadi penting, terlebih di situasi pandemi yang tentunya berkaitan dengan berbagai resiko di tengah masyarakat. Dengan pemberian insentif diharapkan menjadi stimulan bagi para pelaksana di lapangan, khususnya tenaga pendamping dalam pelaksanaan tugas di lapangan. Dalam implementasinya di Kota Salatiga, dukungan anggaran berkaitan dengan insentif diberikan pada tenaga pendamping masyarakat baik dari unsur TKSK, Tenaga Pendamping Program Keluarga Harapan (PKH), maupun tenaga pendamping lainnya dan surveyor yang melakukan pendataan terhadap kelompok sasaran. 
Aspek Komunikasi, Transmision: proses transmisi dilakukan secara simultan dan berkelanjutan oleh semua pihak yang terkait dengan sosialisasi dan internalisasi informasi dengan berbagai media. Proses penyampaian informasi atau pergerakan informasi dilakukan secara langsung antar aktor ataupun dengan penyampaian surat edaran/selebaran/brosur yang diedarkan secara berkelanjutan dan merata di semua kelurahan. Kejelasan: komunikasi dan kejelasan informasi adalah jantung dari hubungan antara satu entitas dengan entitas lainnya. Hal-hal sederhana berupa komunikasi dan kejelasan informasi menjadi hal yang sangat krusial saat terjadi perubahan keadaan. Dengan penjelasan yang terang ketika ada perubahan kondisi, dua entitas yang sedang berkolaborasi bisa bergerak dan bertindak lebih tenang dan sinergis sehingga menghasilkan keluaran yang lebih baik bagi masing-masing entitas maupun kolaborasi keduanya. Dalam konteks implementasi Pro Poor Budgeting di Kota Salatiga, hal tersebut nampak dari adanya sosialisasi dan internalisasi yang terus dilakukan oleh Pemerintah Kota Salatiga melalui berbagai media maupun oleh fasilitator seperti TKSK dan Pendamping PKH. Namun demikian arus diakui bahwa di Kota Salatiga secara umum masih terdapat kelemahan dalam aspek komunikasi, yaitu masih simpang siurnya informasi yang berkaitan dengan mekanisme pemberian bantuan sosial bagi masyarakat dan kelompok terdampak sehingga terdapat beberapa kelompok penerima manfaat yang tidak memahami atau justru kebingungan dengan mekanisme pelaksanaan program. Konsistensi: konsistensi akan mendorong atau meningkatkan kepercayaan (trust) dari pihak penerima informasi. Dalam konteks pelaksanaan desa mandiri pangan, konsistensi dapat dilihat dari benar tidaknya informasi yang disampaikan oleh pengelola program desa mandiri pangan. Kesimpangsiuran informasi dapat menurunkan kepercayaan publik terhadap pengelolaan anggaran untuk masyarakat miskin, terutama bagi mereka yang terdampal Covid-19. Hal tersebut nampak bahwa di Kota Salatiga masih dirasakan kurangnya sosialisasi dan internalisasi, baik dari aspek frekuensi maupun dari aspek substansi.

\section{SIMPULAN}

Implementasi Pro Poor Budgeting merupakan bentuk komitmen pemerintah dalam upaya percepatan penanggulangan kemiskinan, dimasa Pandemi Covid-19 kebijakan penanggulangan kemiskinan melalui Pro Poor Budgeting diselaraskan dengan refokusing anggaran dan prioritas penanganan pandemi Covid-19. Implementasi proses perencanaan penganggaran Pro Poor Budgeting di Kota Salatiga meskipun dilakukan dalam situasi darurat akan tetapi merujuk pada prinsip perencanaan dan penganggaran, yaitu prinsp transparansi, rasional, akuntabel, dan adil dan proporsional. Keempat prinsip tersebut secara jelas tertuang dalam proses perencanaan dan penganggaran untuk penanggulangan kemiskinan yang tersebar dalam berbagai Organisasi Perangkat Daerah. Selanjutnya dalam implementasi Pro Poor Budgeting, terdapat 3 (tiga) isu strategis yang menjadi fokus perhatian: (1) Sinkronisasi data keluarga miskin dengan data dari masyarakat/kelompok terdampak dari mitra binaan yang dimiliki oleh Perangkat Daerah terkait; (2) Standart Operasional Prosedur (SOP) terkait dengan pelaksanaan program, terutama yang berkaitan dengan masyarakat/kelompok masyarakat terdampak; dan (3) Inovasi program dan kegiatan yang mempunyai daya ungkit bagi penguatan ekonomi masyarakat. Terkait dengan hal tersebut terdapat 4 (empat) aspek yang menjadi kunci penting yaitu struktur birokrasi, sumberdaya, disposisi, dan komunikasi. Keempat aspek yang diimplementasikan secara terintegrasi ini menjadi kunci dan tolok ukur keberhasilan implementasi Pro Poor Budgeting di Kota Salatiga. Selain itu, keempat aspek ini juga menjadi pijakan dalam prinsip dalam penentuan penganggaran bagi warga miskin. Selaras dengan hal tersebut, maka anggaran bagi warga miskin, baik yang merujuk pada program penanggulangan kemiskinan tahun 2020, maupun dikaitkan ketiga program prioritas anggaran bagi warga terdampak Covid-19 yang berpotensi memunculkan kelompok miskin baru, proses penganggaran bagi program penanggulangan kemiskinan sudah memperhatikan prinsip dalam Pro 
Poor Budgeting yaitu: Sasaran adalah warga/kelompok miskin, fokus pada akar masalah kemiskinan, memaksimal manfaat bagi orang miskin, melibatkan partisipasi/peran serta warga miskin.

\section{REFERENSI}

Bappeda Kota Salatiga (2020). Laporan Monitoring dan Evaluasi Program Penanggulangan Kemiskinan Kota Salatiga Tahun 2020. Salatiga: Bappeda Kota Salatiga.

Covid-19, G. T. (2020). Protokol Percepatan Penanganan Pandemi Covid-19 (Corona Virus Disease 2019). 19, 31. https://covid19.go.id/storage/app/media/Protokol/Protokol Percepatan Penanganan Pandemi Corona Virus Disease 2019.pdf

Edwards, G. C. (1984). Implementing public policy: Edwards, George C : Free Download, Borrow, and Streaming : Internet Archive. Jai Press Inc.

https://archive.org/details/implementingpubl0000edwa/page/n3/mode/2up?view=theater

Harry. (2009). Keberpihakan Kebijakan Anggaran Pemerintah Daerah terhadap Penduduk Miskin : 19(2), 126-143. https://jurnal.ugm.ac.id/populasi/article/view/12132/8895

Padriyansyah. (2015). Analisis Penerapan Dan Perkembangan Pro-Poor Budgeting Di Provinsi Sumatera Selatan Tahun 2009-2013. Jurnal Ilmiah Ekonomi Global Masa Kini, 06(01), 2031.

Salatiga, P. W., Peraturan, P. A., Sebagian, P., Pelaksanaan, K., Pencegahan, P., Penanganan, D. A. N., Rahmat, D., Yang, T., Esa, M., \& Salatiga, W. (2020). BERITA DAERAH KOTA SALATIGA. 1.

Thaariq, R. M., Wahyu, M. F. R., Ningrum, D. R., \& Aidha, C. N. (2020). Kemiskinan Multidimensi dan Risiko COVID-19 di Indonesia. PRAKARSA Working Paper, 1, 1-131.

Vernon, P. (2015). Sustainable development goals. Economist (United Kingdom), 411(8953).

Wahyudi. (2011). Universitas Indonesia Pengaruh Alokasi Belanja Daerah Untuk ( Studi Kasus Kabupaten / Kota Di Provinsi Jawa Tengah Tahun 2007-2009 ).

Wahyuningsih, W. (2018). Millenium Develompent Goals (Mdgs) Dan Sustainable Development Goals (Sdgs) Dalam Kesejahteraan Sosial. Bisma, 11(3), 390.

https://doi.org/10.19184/bisma.v11i3.6479

Wibisono, N. (2010). ANALISIS KINERJA DAN KEBERPIHAKAN APBD UNTUK RAKYAT (STUDI KASUS DI KOTA MADIUN TAHUN 2004-2008). 